\title{
PENGARUH STANDAR AKUNTANSI PEMERINTAHAN, SISTEM PENGENDALIAN INTERN PEMERINTAH DAN AUDITOR INTERNAL TERHADAP KUALITAS LAPORAN KEUANGAN PEMERINTAH
}

\author{
Ady Kurnia Munggaran ${ }^{1 *}$, Suratno dan Muhammad Yusuf ${ }^{2}$ \\ Magister Akuntansi Universitas Pancasila Jakarta, Indonesia ${ }^{1,2}$ \\ Email: ady.mungga@gmail.com, soeratno_54@yahoo.com,moch.yusuf@ibs.ac.id
}

\begin{tabular}{|c|c|}
\hline \multicolumn{2}{|c|}{ Artikel info } \\
\hline \multicolumn{2}{|c|}{ Artikel history } \\
\hline Diterima & $: 09-11-2020$ \\
\hline Direvisi & : 10-12-2020 \\
\hline Disetujui & : 18-12-2020 \\
\hline
\end{tabular}

Kata kunci: Kualitas Laporan Keuangan; Standar

Akuntansi Pemerintahan; Sistem Pengendalian Intern Pemerintah; Peran Auditor Internal

Keywords: Quality of Financial Statements; Government Accounting Standards; Government Internal Control System; Internal

\begin{abstract}
Abstrak
Penelitian ini bertujuan untuk meneliti pengaruh standar akuntansi pemerintahan, sistem pengendalian intern pemerintah dan peran auditor internal terhadap kualitas laporan keuangan, dengan obyek penelitian pada Kementerian Sosial. Populasi pada penelitian ini sebanyak 93 orang yang yang merupakan pejabat struktural serta fungsional keuangan serta auditor internal pada satuan kerja pusat Kementerian $\mathrm{X}$ dan sample penelitian ini melibatkan 48 responden dengan metode purposive sampling dalam pemilihan samplenya. Penelitian ini menggunakan metode analisis statistik dengan menggunakan bantuan SPSS ver. 21. Hasil pengujian seluruh hipotesis, penelitian ini menunjukkan bahwa, secara simultan variabel independen standar akuntansi pemerintahan (X1), sistem pengendalian intern pemerintahan (X2), dan auditor interna pemerintah (X3) berpengaruh signifikan terhadap kualitas laporan keuangan (Y). Sedangkan secara parsial variabel standar akuntansi pemerintahan (X1) memberikan pengaruh signifikan terhadap kualitas laporan keuangan (Y), sistem pengendalian intern pemerintahan (X2) berpengaruh signifikan terhadap kualitas laporan keuangan (Y), dan auditor internal pemerintah (X3) tidak berpengaruh signifikan terhadap kualitas laporan keuangan (Y).
\end{abstract}

\begin{abstract}
This study aims to examine the effect of government

accounting standards, government internal control systems and the role of internal auditors on the quality of financial reports, with the object of research at the Ministry of Social Affairs. The population in this study were 93 people who were structural and financial functional officials as well as internal auditors at the central work unit of the Ministry of $X$ and the sample of this study involved 48 respondents using purposive sampling method in selecting the sample. This study uses statistical analysis methods using SPSS ver. 21. The results of testing all hypotheses, this study shows that, simultaneously the independent variable government accounting standards (X1), government internal control system (X2), and government internal auditors (X3) have a significant effect on the quality of financial statements $(Y)$. . While partially the government accounting standard variable (X1) has a significant effect on the quality of financial reports $(Y)$, the government internal control system (X2) has a significant effect on the quality of financial reports $(Y)$, and government internal auditors $(X 3)$ have no effect. significant to the quality of financial statements $(Y)$..
\end{abstract}

Koresponden author: Ady Kurnia Munggaran

Email: ady.mungga@gmail.com artikel dengan akses terbuka dibawah lisensi

CC BY SA

2020

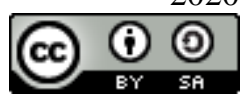

\section{Pendahuluan}

Saat ini, masalah kualitas laporan keuangan menjadi semakin penting.Beberapa kasus 
di mana kualitas laporan keuangan pemerintah pusat dan daerah di Indonesia masih buruk masih menjadi isu hangat dan perlu dikaji lebih lanjut. Laporan keuangan harus memiliki karakteristik yang relevan, andal, sebanding dan mudah dipahami. Munculnya permasalahan tersebut menunjukkan masih kurangnya pemahaman tentang standar akuntansi pemerintah dan sistem pengendalian intern, serta peran auditor internal yang masih kurang dalam memberikan rambu-rambu pengawasan, dan tanda-tanda tersebut berdampak negatif terhadap kualitas laporan keuangan pemerintah pusat.

Seiring waktu, beberapa perubahan telah terjadi dalam penggunaan yayasan akuntansi pemerintah Indonesia. Ketentuan terkait penerapan standar akuntansi pemerintahan berbasis akrual pertama kali diatur dalam Undang-Undang Nomor 17 tentang Keuangan Negara pada tahun 2003. Undang-undang mewajibkan pemerintah menyampaikan sistem pertanggungjawaban APBN / APBD dalam bentuk laporan keuangan berbasis akrual sebelum tahun anggaran 2008. Namun secara umum ketentuan undang-undang hanya dapat bertanggung jawab atas pelaksanaan APBN / APBD tahun 2015 sesuai dengan ketentuan Peraturan Pemerintah Nomor 71. Mengenai standar akuntansi pemerintahan tahun 2010 (Republik Indonesia, 2010). PP menetapkan bahwa laporan keuangan pertanggungjawaban APBN / APBD harus disusun secara akrual mulai tahun anggaran (TA) 2010. Jika pemerintah tidak dapat menerapkan sistem akrual SAP tahun itu, pemerintah dapat menggunakan kas untuk sistem akrual dalam waktu 4 tahun setelah tahun anggaran 2010.

Grafik tersebut menunjukkan bahwa selama periode 2010-2014 realisasi opini WTP mengalami peningkatan, namun di sisi lain jumlah LKKL yang menerima opini TMP juga meningkat, hal ini menunjukkan bahwa pemerintah pusat mendukung pelaporan keuangan berbasis akrual. Aspek tersebut belum sepenuhnya efektif (Finance, 2015).

BPK sendiri memberikan opini Wajar Tanpa Pengecualian (WDP) tahun 2013-2015 atas hasil audit laporan keuangan pemerintah pusat (LKPP). BPK menekankan kualitas Laporan Keuangan Kementerian / Lembaga (LKKL) yang masih bermasalah. Harry Azhar Aziz (2016) mengatakan bahwa masalah tersebut merupakan kombinasi dari standar 
akuntansi pemerintahan yang tidak konsisten, sistem pengendalian internal yang lemah, dan ketidakpatuhan terhadap peraturan perundang-undangan.

Standar akuntansi pemerintahan adalah prinsip akuntansi yang ditetapkan pada saat menyusun dan menyampaikan laporan keuangan pemerintah. Tujuan dari operasi ini agar laporan keuangan yang dihasilkan dapat meningkatkan kualitas laporan keuangan pemerintah pusat.

Dengan menerapkan standar akuntansi yang baik, pemerintah akan memperoleh informasi yang berkualitas karena laporan keuangan pemerintah harus sesuai dengan standar akuntansi pemerintahan. Pernyataan ini sejalan dengan hasil penelitian (Nugraheni \& Subaweh, 2011) yang menunjukkan bahwa penerapan standar akuntansi pemerintahan berdampak pada peningkatan kualitas laporan keuangan.

Pelaporan keuangan dengan nilai informasi yang berkualitas tinggi tidak terlepas dari penerapan pengendalian internal pemerintah yang baik. Hal ini sesuai dengan penelitian yang dilakukan oleh (Herawati, 2014) yang menunjukkan bahwa sistem pengendalian internal berpengaruh positif dan signifikan terhadap kualitas laporan keuangan, hingga $83 \%$.

Diharapkan melalui penguatan sistem pengendalian intern pemerintah, upaya peningkatan kualitas laporan keuangan pemerintah dapat ditingkatkan sehingga di kemudian hari diperoleh opini Wajar Tanpa Pengecualian. Hal ini karena memperoleh laporan keuangan Wajar Tanpa Pengecualian berarti pengguna laporan keuangan dapat mempercayai laporan tersebut sebagai alat pengambilan keputusan. Selain itu, penerapan sistem pengendalian internal dapat mencegah terjadinya aktivitas yang tidak sesuai dengan ketentuan yang berlaku. Dengan cara ini dapat diperoleh efisiensi, manfaat dan ekonomi dalam implementasi dan pembangunan.

Selain penerapan standar akuntansi pemerintahan dan sistem pengendalian intern pemerintah yang baik, peran auditor internal juga diperlukan untuk memantau dan memberikan jaminan kualitas untuk memastikan keduanya telah dilaksanakan dengan baik. Mengingat lambatnya perkembangan kualitas laporan keuangan, peningkatan peran auditor internal dan efektivitas pengendalian internal pemerintah menjadi sangat penting. Terkait masalah pengendalian, pemerintah telah menerbitkan PP No. Tentang Sistem Pengendalian Intern Pemerintah (SPIP) No. 60 Tahun 2008 (Republik Indonesia, 2008). Diharapkan dengan optimalisasi SPIP, pengendalian internal menjadi lebih efektif yang dapat berperan dalam menyelesaikan masalah informasi keuangan yang berkualitas rendah.

Melalui penelitian ini, peneliti bertujuan untuk memahami pengaruh penerapan pengendalian intern pemerintah, standar akuntansi yang berlaku bagi pemerintah, dan peran auditor internal dalam memantau kualitas informasi yang dihasilkan oleh laporan keuangan. Peneliti berharap penelitian ini bermanfaat bagi Kementerian Keuangan dalam proses pengambilan keputusan terkait tata kelola keuangan dan penguatan sistem pertanggungjawaban pengawasan.Selain itu, peneliti berharap penelitian ini dapat menjadi referensi untuk penelitian selanjutnya. 


\section{Metode Penelitian}

Jenis penelitian ini adalah penelitian deskriptif dan kuantitatif. Peneliti memilih jenis penelitian ini karena data yang diperoleh dari keseluruhan sampel bersifat kualitatif, kemudian disimpulkan dan dianalisis berdasarkan metode statistik yang digunakan.

Tujuan penelitian ini dilakukan di Bagian X. Lokasi tersebut dipilih karena peneliti tertarik dengan opini BPK-RI atas laporan keuangan (LK) Departemen X yang mengalami penurunan dalam tiga tahun terakhir. Bagian $\mathrm{X}$ dianugerahi predikat "No Comments" pada tahun 2015, atau disclaimer bukanlah hasil terbesar, dan menunjukkan bahwa masih banyak kelemahan dalam penerapan standar akuntansi pemerintahan dan pengendalian intern, yang tercermin dari hasil survei BPK dan Usul.

Penelitian ini akan mengungkap standar akuntansi pemerintahan, penerapan sistem pengendalian intern pemerintah, dan pengaruh auditor internal terhadap kualitas laporan keuangan pemerintah. Penelitian ini dilakukan untuk para manajer keuangan pada departemen kerja eselon I departemen kerja kantor pusat.

Data asli merupakan informasi tangan pertama yang peneliti miliki terkait dengan variabel-variabel yang diminati untuk tujuan penelitian tertentu (Sekaran, 2006: 60). Dalam penelitian ini data utama diperoleh dengan bantuan alat angket yang berkaitan dengan variabel penelitian dan hasil wawancara terhadap responden.

Sugiyono (2008: 402) mengemukakan bahwa sumber data pembantu adalah sumber data yang tidak secara langsung memberikan data kepada pengumpul data. Data pembantu ini merupakan data yang mendukung kebutuhan data utama. Dalam penelitian ini, data pembantu yang digunakan oleh peneliti adalah Peraturan Pemerintah Nomor 71 Tahun 2010 tentang Standar Akuntansi Pemerintahan, Peraturan Pemerintah Nomor 60 Tahun 2008 tentang Sistem Pengendalian Intern Pemerintah, Buku-buku terkait variabel yang akan diteliti dan lain-lain. literatur.

Populasi merupakan seluruh objek yang akan diteliti dalam sebuah penelitian. Sugiyono (2013:115) menyatakan bahwa populasi merupakan wilayah generalisasi yang terdiri dari atas objek dan subjek yang mempunyai kuantitas dan karakteristik tertentu yang ditetapkan oleh peneliti untuk dipelajari dan ditarik kesimpulannya. Populasi dalam penelitian ini adalah seluruh pengelola keuangan pada 7 (tujuh) Unit Kerja Eselon I (UKE I) di Kantor Pusat serta Pejabat Fungsional Auditor berjumlah 93 orang.

Variabel yang digunakan dalam penelitian ini adalah sebagai berikut:

1. Variabel bebas (bebas) adalah variabel yang mempengaruhi atau menyebabkan variabel terikat berubah atau muncul variabel terikat (Sugiyono, 2013: 59). Variabel independen dalam penelitian ini adalah penerapan standar akuntansi pemerintahan (X1), sistem pengendalian intern pemerintah (X2), dan peran auditor internal (X3).

2. Variabel terikat (dependent variable) adalah variabel yang dipengaruhi oleh atau menjadi hasil dari suatu variabel bebas (Sugiyono, 2013: 59). Variabel terikat dalam penelitian ini adalah kualitas laporan keuangan pemerintah (Y).

Alat yang digunakan dalam penelitian ini adalah kuesioner. Kuesioner digunakan untuk memperoleh data tentang penerapan standar akuntansi pemerintahan, sistem pengendalian intern pemerintah, peran auditor internal, dan kualitas laporan keuangan Departemen X. 
Indikator variabel terikat diperoleh dari Peraturan Pemerintah SAP No. 71/2010. Data variabel independen X1 diperoleh dari PP/71/2010 terkait SAP, X2 diperoleh dari PP 60/2008 terkait SPIP, dan X3 diolah oleh Lembaga Auditor Internal (1999). Indikator yang digunakan untuk setiap variabel penelitian sudah jelas.

Kuesioner dalam penelitian ini berbentuk skala hierarki (skala liket), dengan lima alternatif jawaban, dan setiap pertanyaan mendapat skor. Skala likert lima poin merupakan skala yang paling umum digunakan dalam penelitian, dengan indeks validitas, reliabilitas, diskriminasi dan stabilitas yang cukup baik (Budiaji, 2013).

Skala likert dari variabel yang akan diukur diubah menjadi indikator variabel, dan indikator tersebut kemudian digunakan sebagai titik tolak penyusunan proyek alat, yang dapat berupa pernyataan atau pertanyaan (Sugiyono, 2013: 133). Skala likert lima poin digunakan untuk pengukuran setiap variabel dalam penelitian ini, yaitu: 1 = sangat tidak setuju (STS), 2 = tidak setuju $(\mathrm{TS}), 3=$ netral $(\mathrm{N}), 4=$ setuju $(\mathrm{S}), 5=$ Setuju sekali $(\mathrm{SS})$.

Analisis data merupakan bagian yang sangat penting dalam penelitian, karena analisis data merupakan upaya untuk menemukan jawaban atas pertanyaan yang muncul. Metode penelitian adalah suatu metode kerja yang sistematis dan sistematis yang bertujuan untuk memperoleh hasil yang memadai dalam penelitian ilmiah. Penelitian ini menggunakan data mentah melalui kuesioner yang dikirimkan langsung kepada responden. Analisis data dalam penelitian ini menggunakan bantuan program analisis komputer.

Setelah menentukan skor pernyataan, hipotesis harus diuji. Hipotesis ini merupakan jawaban sementara atas pertanyaan penelitian, dan kebenarannya masih perlu diuji secara empiris. Dalam model yang digunakan dalam penelitian ini variabel dependennya adalah kualitas laporan keuangan, sedangkan variabel independennya adalah penerapan standar akuntansi pemerintahan, sistem pengendalian intern pemerintah, dan peran auditor internal.

Metode penelitian ini dalam persamaan regresi dapat dituliskan sebagai berikut :

Keterangan :

$\mathrm{Y}=$ Kualitas Laporan Keuangan

$\mathrm{X} 1=$ Penerapan Standar Akuntansi Pemerintah

$\mathrm{X} 2=$ Sistem Pengendalian Intern Pemerintah

X3 = Peran Auditor Internal

ó $\quad=$ konstanta

$=$ Error term

$1=$ Koefisien Variabel X1

$2=$ Koefisien Variabel X2

$3=$ Koefisien Variabel X3

Tahap pengujian regresi berganda dapat menjawab hipotesis yang disajikan:

a. Satu jenis. Korelasi product-moment digunakan untuk menguji validitas data dalam penelitian ini dengan taraf signifikansi 5\%. Jika total korelasi semua item pada item yang dikoreksi-variabel sumber daya manusia lebih besar dari koefisien korelasi pada $r$ tabel maka pernyataan dalam kuesioner dianggap valid.

b. Pengujian reliabilitas instrument yang digunakan yaitu koefisien Cronbach Alpha instrument masing-masing variabel. Instrumen dikatakan reliabel bila memiliki Cronbach 
Alpha lebih besar 0,60. Uji reliabilitas memperhatikan output reliability statistics pada kolom Cronbach's Alpha.

c. Uji hipotesis klasik Untuk menguji hipotesis klasik dari data asli, peneliti melakukan uji normalitas, multikolinearitas, uji autokorelasi, uji heteroskedastisitas dan uji linieritas.

1) Uji normalitas

Uji normalitas bertujuan untuk menguji apakah variabel dependen dan variabel independen berdistribusi normal dalam model regresi. Model regresi yang baik memiliki distribusi normal atau mendekati distribusi normal. Untuk mengetahui apakah model regresi sudah atau tidak, lakukan analisis grafis dengan melihat "Grafik Laporan Probabilitas Normal", yang membandingkan distribusi kumulatif data aktual dengan distribusi normal. Hal ini dapat dilihat dari plot residual PP normal bahwa setiap pengamatan variabel $\mathrm{Y}$ berdistribusi normal.Jika data didistribusikan disekitar garis diagonal dan mengikuti arah garis diagonal maka model regresi akan memenuhi asumsi normalitas ( Sutanto, 2006).

2) Uji Multikolinieraitas

Digunakan untuk menguji ada tidaknya hubungan sempurna atau hampir sempurna diantara variabel-variabel bebas pada model regresi. Dalam regresi linier tidak boleh terjadi sesama variabel independen berkorelasi secara kuat (multicollinearity). Untuk mendeteksi collinearity dapat diketahui dari nilai Variance Inflation Factor (VIF), bila nilai VIF lebih dari 10 maka mengindikasikan telah terjadi collinearity (Sutanto, 2006).

3) Uji Autokorelasi

Uji Autokorelasi merupakan pengujian yang dilakukan untuk menguji ada tidaknya pengaruh antara variabel pengganggu dalam masing-masing variabel bebas. Untuk mengetahui asuamsi ini dilakukan dengan cara mengeluarkan uji Durbin Watson, bila nilai Durbin -2 s.d. +2 berarti asumsi independensi terpenuhi, sebaliknya bila nilai Durbin $<-2$ atau $>+2$ berarti asumsi tidak terpenuhi (Sutanto, 2006)

4) Uji Heteroskedasitas

Digunakan untuk menguji apakah semua variabel bebas mempunyai varian kesalahan pengganggu yang sama dalam model regresi. Pendeteksian gejala tersebut adalah dengan melihat pola tertentu pada grafik, dimana sumbu $\mathrm{Y}$ adalah residual, sedangkan sumbu $\mathrm{X}$ adalah prediksi.

Jika pada grafik terdapat pada titik-titik yang membentuk suatu pola tertentu dan teratur (bergelombang, melebar, kemudian menyempit) maka telah terjadi Heteroskedasitas. Sebaliknya jika tidak ada pola yang jelas serta titik-titik menyebar diatas dan dibawah angka nol pada sumbu Y, maka tidak terjadi Heteroskedasitas.

5) Uji Linier

Uji linieritas adalah pengujian yang bertujuan untuk mengetahui apakah regresi bersifat linier atau tidak. Untuk mengetahui asumsi linieritas dapat diketahui dari uji ANOVA (overall F test) bila hasilnya signifikan ( $\mathrm{p}$ value<alpha) maka moodel berbentuk linier (Sutanto, 2009).

6) Tahap Uji - t, digunakan untuk menjawab hipotesis parsial atau digunakan untuk menguji koefisien regresi secara individu, dengan ketentuan sebagai berikut : Ho : 1 $=0$, yang berarti tidak terdapat pengaruh antara variabel independent dengan variabel dependent. $\mathrm{H} 1: 1 \neq 0$, yang berarti bahwa ada pengaruh antara variabel - variabel 
independent dengan variabel dependent secara individual. Langkah selanjutnya adalah menentukan signifikansi (á) yaitu sebesar 5\% dengan df $=(n-k)$ untuk menentukan nilai t table. Dilakukan perbandingan dengan t hitung untuk menentukan Ho dan $\mathrm{H} 1$ ditolak atau diterima, dengan ketentuan : Ho diterima dan $\mathrm{H} 1$ ditolak apabila thitung < $\mathrm{t}$ table atau Ho ditolak dan $\mathrm{H} 1$ diterima apabila t hitung $>\mathrm{t}$ table. Untuk mempermudah dan menjamin ketelitian pelaksanaan uji statistik, maka dalam penelitian ini menggunakan program SPSS.

7) Tahap Uji - F, digunakan untuk menjawab hipotesis simultan atau digunakan untuk mengetahui signifikansi seluruh koefisien regresi, dengan langkah sebagai berikut : Ho : $1=2=3=0$, yang berarti tidak ada pengaruh variabel independent terhadap variabel dependent secara bersama - sama. $\mathrm{H} 1: 1 \neq 2 \neq 3 \neq 0$, yang berarti bahwa ada pengaruh variabel independent terhadap variabel dependent secara serempak. Nilai F tabel dengan tingkat signifikansi ( $\alpha)$ sebesar 5\% dan df $=(n-k)(k-1)$, dimana $n=$ jumlah sample, $\mathrm{k}=$ jumlah variabel. Kemudian dilakukan perbandingan dengan $\mathrm{F}$ hitung untuk menentukan Ho dan $\mathrm{H} 1$ diterima atau ditolak, dengan ketentuan : Ho diterima dan $\mathrm{H} 1$ ditolak apabila $\mathrm{F}$ hitung < F tabel atau Ho ditolak dan H1 diterima apabila F hitung > F tabel.

8) Tahap pengolahan data melalui Program SPSS, sehingga akan ditemukan jawaban apakah hipotesis yang telah diajukan sebelumnya akan diterima atau ditolak, disesuaikan dengan nilai signifikansi yang didapat. Program SPSS akan menghasilkan output berupa model summary, anova, coefficient, dan sebagainya, dimana output tersebut menjadi sumber pembahasan hipotesis.

Tahap pembahasan mengenai koefisien determinasi, yaitu kemampuan variabel bebas dalam menjelaskan variabel terikat. Data yang digunakan adalah data adjusted r square dan bukan $r$ square karena variabel bebasnya lebih dari satu.

\section{Hasil dan Pembahasan}

\section{Uji Validitas}

Keseluruhan variabel penelitian yang terdiri dari 42 pertanyaan yang harus dijawab oleh responden adalah valid. Untuk menentukan valid atau tidaknya pertanyaan tersebut adalah apabila terdapat korelasi antara masing-masing indikator terhadap nilai r-hitung menunjukkan hasil yang signifikan dengan tingkat signifikansinya $5 \% \mathrm{df}=\mathrm{n}-2(48-2)=46$ nilai $\mathrm{r}$-tabel $=0,2845$. Maka seluruh butir dinyatakan valid karena memiliki nilai r-hitung lebih tinggi daripada nilai r-tabel.

\section{Uji Reabilitas}

Reliabilitas sebenarnya adalah alat untuk mengukur suatu kuesioner yang merupakan indikator dari variabel atau konstruk. Suatu kuesioner dikatakan reliabel atau handal jika jawaban seseorang terhadap pertanyaan adalah konsisten atau stabil dari waktu ke waktu. Suatu instrumen dapat dikatakan reliabel jika nilai cronbach's alpha berada diatas 0,60 (Ghozali, 2006) dari hasil menunjukkan nilai cronbach alpha yang diperoleh sebesar 0,927 berada diatas 0,60 yang berarti seluruh pertanyaan dalam kuesioner ini reliabel. 


\section{A. Pengujian Asumsi Klasik}

\section{a. Uji Normalitas}

Pengujian normalitas dalam penelitian ini yaitu melalui normal probability plot dengan menggunakan SPPS 21.0 dan diperoleh hasil sebagai berikut:

$$
\text { Grafik } 1
$$

Uji Normalitas

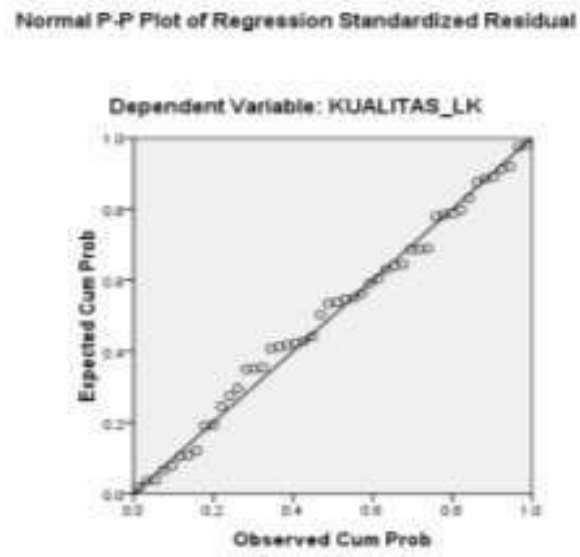

Sumber : Data diolah

Berdasarkan gambar diatas dapat disimpulkan bahwa data dalam penelitian ini memenuhi syarat normal probability plot sehingga model regresi dalam penelitian memenuhi asumsi normalitas (berdistribusi normal). Artinya penelitian ini berasal dari yang berdistribusi normal.

\section{b. Uji Multikolinieritas}

Dari hasil perhitungan tolerance menunjukkan tidak ada variabel independen yang memiliki tolerance kurang dari 0,10 yang berarti ridak ada korelasi antar variabel independen yang nilainya lebih dari $95 \%$.

Hasil perhitungan nilai Variance Inflation Factor (VIF) juga menunjukkan hal yang sama tidak ada satu variabel independen yang memiliki nilai VIF lebih dari 10. Jadi dapat disimpulkan bahwa tidak terdapat multikolinieritas antar variabel independen dalam model regresi.

\section{c. Uji Autokorelasi}

Dalam penelitian ini uji autokorelasi menggunakan tes Durbin Watson, dengan jumlah sampel $\mathrm{n}=48, \alpha=0,05$ dan banyaknya variabel independent $\mathrm{k}=3$, maka didapat nilai kritis $\mathrm{dL}=1,4064$ dan $\mathrm{dU}=1,6708$. Berdasarkan perhitungan maka dapat diketahui nilai Durbin Watson sebesar 1,918. Sehingga DW berada diantara dU $(1,6708)<$ DW $(1,918)<4-\mathrm{dU}(4-1,6708=2,3292)$. Maka dapat disimpulkan bahwa dalam penelitian ini tidak terdapat autokorelasi. Artinya bahwa variabel independent dalam penelitian ini tidak terganggu atau terpenuhi oleh variabel pengganggu.

\section{d. Uji Heterokedasitas}

Model yang dikatakan baik adalah yang homokedastisitas atau tidak terjadi heteroskedastisitas. Sebagai dasar analisis adalah sebagai berikut: 
Grafik 2

\section{Hasil Uji Heterokedastisitas}

scatterplot

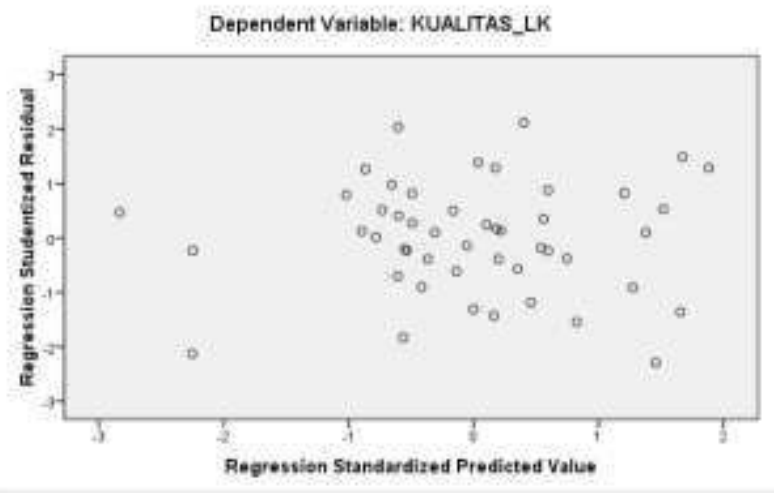

Sumber: Data Diolah

Terlihat dari diagram pencar bahwa titik-titik tersebut tersebar secara acak dan berada di atas atau di bawah angka 0 pada sumbu Y, dan tidak membentuk pola tertentu. Dari gambar di atas dapat disimpulkan bahwa tidak terdapat heteroskedastisitas pada model regresi, sehingga model regresi dinyatakan layak untuk digunakan.

\section{B. Pengujian Linieritas}

Uji linieritas dalam penelitian ini juga menggunakan SPSS 21.0 dan hasil uji Nilai efektif dari tabel analisis varians adalah 0,000. Artinya nilai signifikansi tersebut lebih kecil dari $0,05(0,000<0,05)$ yang berarti hubungannya linier. Hal ini menunjukkan bahwa SAP, SPIP dan auditor internal mempunyai model linier untuk kualitas laporan keuangan

\section{Analisa Regresi berganda}

Dengan menggunakan analisis regresi linier berganda dengan persamaan berikut, dapat dilihat pengaruh SAP (X1), SPIP (X2) dan auditor internal (X3) terhadap kualitas laporan keuangan $(\mathrm{Y})$ :

Kualitas LK $(\mathrm{Y})=\mathrm{B} 0+\mathrm{B} 1 \mathrm{SAP}+\mathrm{B} 2 \mathrm{SPIP}+\mathrm{B} 3 \mathrm{AI}+\mathrm{e}$

Dimana: $\mathrm{Y}=$ kualitas laporan keuangan

B0 $=$ konstan

$\mathrm{B} 1, \mathrm{~B} 2, \mathrm{~B} 3$ = koefisien regresi

SAP $=$ Standar Akuntansi Pemerintahan

SPIP $=$ Sistem Pengendalian Intern Pemerintah

$\mathrm{AI}=$ auditor internal

$\mathrm{e}=$ kesalahan

Hasil analisis regresi berganda menggunakan SPSS 21.0 adalah sebagai berikut:

Melalui perhitungan SPSS diperoleh persamaan regresi linier berganda:

Kualitas LK $(\mathrm{Y})=14.463+0.226 \mathrm{SAP}+0.163 \mathrm{SPIP}+0.42 \mathrm{AI}+\mathrm{e}$

\section{Pengujian hipotesis}

1. Pengujian hipotesis secara simultan (uji F)

Untuk mengetahui pengaruh yang signifikan antara variabel independen terhadap variabel dependen digunakan uji F. Berdasarkan output SPSS diperoleh nilai $\mathrm{F}$ hitung sebesar 14,083. Adapun nilai $\mathrm{F}$ tabel pada taraf signifikansi 5\% dan derajat 
kebebasan (df1) dari k-1 (3-1 = 2) dan penyebut nk (48-3 = 45) (df2) adalah 320 Jika kedua nilai tersebut dibandingkan maka nilai $\mathrm{F}$ hitung lebih besar dari $\mathrm{F}$ tabel $(14,083>3,20)$, sehingga Ho ditolak. Dengan demikian dapat disimpulkan bahwa pada saat yang sama variabel independen (SAP, SPIP dan peran auditor internal) memiliki pengaruh positif yang signifikan terhadap kualitas laporan keuangan.

2. Uji Parsial (Uji t)

Dengan menggunakan taraf signifikansi 5\% dan nilai df n-k-1 $(48-3-1=44)$ maka diperoleh nilai t tabel 2.015.

Hasil pengujian pengaruh masing-masing variabel independen (SAP, SPIP dan peran auditor internal) terhadap variabel dependen (kualitas laporan keuangan) adalah sebagai berikut:

a) Dampak SAP terhadap kualitas laporan keuangan

Diketahui bahwa nilai t hitung 2,522 lebih besar dari nilai t tabel. Lalu kenapa ditolak. Dengan demikian, dapat disimpulkan bahwa variabel SAP memiliki pengaruh yang signifikan terhadap kualitas laporan keuangan.

b) Dampak SPIP terhadap kualitas laporan keuangan

Diketahui bahwa nilai t hitung 3,302 lebih besar dari nilai t tabel. Lalu kenapa ditolak. Dengan demikian dapat disimpulkan bahwa variabel SPIP memiliki pengaruh yang signifikan terhadap kualitas laporan keuangan.

c) Pengaruh peran auditor internal terhadap kualitas laporan keuangan

Diketahui bahwa t hitung sebesar 0,175 maka t hitung yang diperoleh lebih kecil dari nilai $\mathrm{t}$ tabel. Bagaimana ini bisa diterima. Dengan demikian dapat disimpulkan bahwa peran variabel auditor internal tidak berpengaruh signifikan terhadap kualitas laporan keuangan.

3. Uji Determinan $\left(\mathrm{R}^{2}\right)$

Terlihat dari keluaran SPSS bahwa koefisien determinasi atau R Square sebesar 0,455 atau 45,50\%. Hal ini menunjukkan bahwa variabel yang diteliti (SAP, SPIP dan peran auditor internal) memberikan pengaruh sebesar 45,50\% terhadap kualitas laporan keuangan, sedangkan variabel sisanya dipengaruhi oleh variabel lain yang belum diteliti (variabel confounding).

Dari hasil uji yang telah dilakukan maka diketahui bahwa:

a. Satu jenis. Standar akuntansi pemerintahan (SAP) memiliki pengaruh yang signifikan terhadap kualitas laporan keuangan, artinya semakin baik penerapan standar akuntansi pemerintahan dalam proses pelaporan dan pencatatan keuangan maka akan semakin baik pula kualitas laporan keuangan yang dihasilkan. Hal ini sesuai dengan temuan penelitian sebelumnya (Nugraheni \& Subaweh, 2011) yang direview oleh Biro Inspeksi Kementerian Pendidikan dan (Komarudin, 2013), yang menemukan bahwa standar akuntansi pemerintahan mempunyai pengaruh yang signifikan terhadap kualitas laporan keuangan.

b. Sistem pengendalian internal pemerintah (SPIP) memiliki pengaruh yang signifikan terhadap kualitas laporan keuangan. Ini membuktikan bahwa SPIP yang bekerja dengan baik akan meningkatkan kualitas laporan keuangan. Hal ini sejalan dengan temuan penelitian sebelumnya (Udiyanti, Ni Luh Nyoman, 2014) review SKPD Kabupaten Buleleng dan (Putra \& Amar, 2015), yang menemukan bahwa sistem 
pengendalian intern pemerintah berpengaruh signifikan terhadap kualitas pelaporan keuangan.

c. Peran auditor internal tidak berpengaruh terhadap kualitas laporan keuangan. Hal ini menunjukkan bahwa auditor internal bukanlah pilihan terbaik dalam menjalankan jasa asuransinya dan konsultasi sebagai auditor, terutama dalam hal penjaminan kualitas laporan keuangan. Hal ini mematahkan hasil penelitian sebelumnya (Amalia \& Laksito, 2014) yang menemukan bahwa peran auditor internal berpengaruh positif terhadap kualitas laporan keuangan.

d. Sistem pengendalian internal pemerintah dan peran auditor internal memiliki pengaruh yang signifikan terhadap kualitas laporan keuangan. Hal ini sejalan dengan penelitian sebelumnya yang dilakukan oleh Pemerintah Provinsi NTB terhadap SKPDSKPD (Fikri et al., 2015) yang menunjukkan bahwa penerapan SAP, kapabilitas perangkat, fungsi audit internal dan SPIP berpengaruh terhadap kualitas informasi laporan keuangan.

\section{Kesimpulan}

Hasil analisis regresi linier berganda untuk menguji hipotesis terdapat 3 (tiga) variabel independen yaitu standar akuntansi pemerintahan, sistem informasi akuntansi, peran auditor internal, dan 1 (satu) variabel dependen (kualitas laporan keuangan). Bagian ini menunjukkan pengaruh signifikan variabel standar akuntansi pemerintahan. Mengenai kualitas laporan keuangan. Hal tersebut menunjukkan bahwa standar akuntansi pemerintahan telah memberikan kontribusi yang positif terhadap kualitas laporan keuangan. Variabel-variabel sistem pengendalian intern pemerintah mempunyai pengaruh yang signifikan terhadap kualitas laporan keuangan sampai batas tertentu, sedangkan peran auditor internal tidak memiliki pengaruh parsial terhadap kualitas laporan keuangan. Hal ini menunjukkan bahwa peran auditor internal sebagai penjamin kualitas dalam penelaahan dan konsultasi penyelesaian laporan keuangan belum optimal. Sedangkan secara Simultan Variabel standar akuntansi pemerintah, sistem informasi akuntansi, dan peran auditor internal berpengaruh terhadap kualitas laporan keuangan.

Peneliti menemukan batasan dalam penelitian ini yaitu jumlah sampel penelitian yang memenuhi standar belum optimal, sehingga tidak dapat diperluas ke semua kementerian dan komisi, dan penelitian ini menggunakan metode survei kuesioner, sehingga kesimpulannya didasarkan pada penggunaan Berasal dari data yang dikumpulkan dalam dokumen tertulis. Beberapa responden yang kurang teliti membaca kuesioner sehingga membuat mereka tidak terlalu serius dalam menanggapi kuesioner, dan menemukan bahwa data jawaban tidak konsisten. 
Ady Kurnia Munggaran, Suratno dan Muhammad Yusuf

\section{Bibliografi}

Amalia, S. R. N., \& Laksito, H. (2014). Pengaruh Auditor Internal Terhadap Kualitas Pelaporan Keuangan Pada Bank Perkreditan Rakyat di Jawa Tengah. Fakultas Ekonomika dan Bisnis.

Budiaji, W. (2013). Skala pengukuran dan jumlah respon skala likert. Jurnal Ilmu Pertanian Dan Perikanan, 2(2), 127-133.

Fikri, M. A., Inapty, B. A., \& Martiningsih, S. P. (2015). Pengaruh penerapan standar akuntansi pemerintahan, kompetensi aparatur dan peran audit internal terhadap kualitas informasi laporan keuangan dengan sistem pengendalian intern sebagai variabel moderating (Studi empiris pada SKPD-SKPD di Pemprov. NTB). Simposium Nasional Akuntansi XVIII.

Ghozali, I. (2006). Aplikasi Analisis Multivariate Dengan Program SPSS, Cetakan IV. Semarang: Badan Penerbit Universitas Diponegoro., 2012. Aplikasi Analisis Multivariate Dengan Program SPSS 20, Edisi, 6.

Herawati, T. (2014). Pengaruh Sistem Pengendalian Intern Terhadap Kualitas Laporan Keuangan (Survei Pada Organisasi Perangkat Daerah Pemda Cianjur). STAR-Study \& Accounting Research, 11(1), 1-14.

Keuangan, B. P. (2015). Pendapat BPK Kesiapan Pemerintah Dalam Pelaporan Keuangan Berbasis Akrual Tahun 2015. BPK-RI. Jakarta. Nur Mayani, A. Faroby Falatehan Strategi Peningkatan Kesiapan Sumber Daya Manusia.

Komarudin, Y. (2013). Pengaruh Penerapan Standar Akuntansi Pemerintahan dan Sistem Pengendalian Intern Terhadap Kualitas Laporan Keuangan (Studi Penelitian Pada Instansi Pemerintah Kota Bandung). Skripsi. Universitas Komputer Indonesia. Bandung.

Nugraheni, P., \& Subaweh, I. (2011). Pengaruh Penerapan Standar Akuntansi Pemerintahan Terhadap Kualitas Laporan Keuangan. Jurnal Ilmiah Ekonomi Bisnis, 13(1).

Putra, B. D., \& Amar, S. (2015). Pengaruh Kompetensi Sumber Daya Manusia, Penerapan Sistem Pengendalian Intern Pemerintah, dan Penerapan Standar Akuntansi Pemerintah Terhadap Kualitas Laporan Keuangan Pemerintah Kota Padang. Jurnal Riset Manajemen Bisnis Dan Publik, 3(1).

Republik Indonesia. (2008). Peraturan Pemerintah Nomor 60 Tahun 2008 Tentang Sistem Pengendalian Intern Pemerintah.

Republik Indonesia. (2010). Peraturan Pemerintah Nomor 71 tahun 2010 Tentang Standar Akuntansi Pemerintahan.

Udiyanti, Ni Luh Nyoman, dkk. (2014). Pengaruh Penerapan Standar Akuntansi Pemerintahan, Sistem Pengendalian Internal dan Kompetensi Staf Akuntansi Terhadap Kualitas Laporan Keuangan Pemerintah Daerah. Jurnal Akuntansi Program S1 UPG Singaraja, 2(1). 